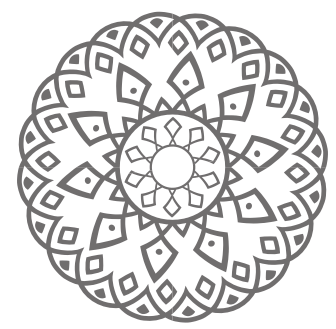

\title{
Maqúsid Al-Sharí'At: The Main Reference AND ETHICAL-SPIRITUAL FOUNDATION FOR THE Dynamization Process of Islamic LaW
}

\author{
Iffatin Nur, Syahrul Adam, M. Ngizzul Muttaqien
}

\begin{abstract}
Abstrak: Peran paling utama dan penting maqāsid al-sharīat yang patut dipelajari adalah sistem direktif dan pertahanan. Sistem direktif, misalnya, menempatkan maqāsid al-sharíat sebagai rujukan utama untuk setiap reformasi atau proses perubahan dan dinamisasi hukum Islam, sedangkan yang terakhir menempatkannya sebagai prinsip moralitas tertinggi yang memberikan landasan dan kekuatan etis-spiritual untuk masyarakat Muslim ketika mereka berinteraksi dengan hukum. Dengan dua peran tersebut, maqāsid al-sharīat dapat menjadi pendorong perubahan masa depan menuju masyarakat yang lebih konstruktif dan humanistik. Penelitian pustaka ini meneliti maqāsid al-sharī'at dari masa Nabi Muhammad Saw. hingga hari ini. Hal ini bertujuan untuk menguraikan posisi maqūsid al-sharíat sebagai acuan utama dan landasan etis-spiritual bagi dinamisasi proses hukum Islam dalam menghadapi persoalan kontemporer. Ini juga mengkaji konsep maqūsid al-sharíat dan menganalisis fleksibilitas, kemampuan beradaptasi, dan dinamika hukum Islam. Selain itu, dimaksudkan untuk membuka pikiran mereka yang menyatakan bahwa hukum Islam begitu lestari, doktrinal, abadi, dan final sehingga dianggap tidak dapat beradaptasi dengan berbagai bentuk perubahan sosial dan modernisasi yang membawa banyak isu kekinian.
\end{abstract}

Kata kunci: Masalah-masalah Kontemporer; Dinamisasi; Landasan etika-spiritual; Maqūsid al-Sharīat 
Abstract: The two primary and significant roles of maqūsid al-sharíat worth studying are directive and defensive systems. The directive system, for instance, puts the maqussid al-sharíat as the main reference for any reformation or changing processes and dynamization of the Islamic law, whereas the latter places it as the supreme principle of morality that provides the foundation and ethical-spiritual power for Muslim Societies when they interact with the law. With these two roles, the maqūsid al-sharīat can serve as a driving force to create future changes towards a more constructive and humanistic society. This study is library research which examines the maqūsid al-sharíat from the time of Prophet Muhammad (Peace be Upon Him) to this very day. It aims at elaborating the position of maquasid al-shari'at as the primary reference and ethical-spiritual foundation for the dynamization process of Islamic law in dealing with contemporary issues. It also examines the concept of maquasid al-sharìat and analyzes the flexibility, adaptability, and dynamic of Islamic law. In addition, it is intended to open the mind of those who claim that Islamic law is so immutable, doctrinal, eternal, and final. This means that Islamic law is assumed to be inadaptable to various forms of social changes and modernization.

Keywords: Contemporary Issues; Dynamization; Ethical-spiritual Foundation; Maqūsid al-Sharīat 


\section{Introduction}

Allah established the Islamic law to give benefits to human beings and to prevent any mafsadāt (harms), both in this world and the hereafter (Syabani, 2015: 127- 142). Creating benefits is crucial in the formulation of law, - These laws include the divine law deriving from a transcendent source (revelation) as in the Islamic law and the human-made law-, although each law has their respective emphasis (Bakrie, 1996: 130).

Concerning the Islamic law, the difference is in the privilege of the law itself. In the meantime, lots of contemporary public issues including democracy, general election, parliamentary system, corruption, life and health insurances, stem cell therapy, and alike need a critical, wise and thorough reviews by applying the maquasid al-sharī'at (the objectives of Islamic law) In Indonesia, for example, democracy which is manifested in general elections, usually taking place every five years, has been accepted as a means to elect the head of central, provincial, and local governments as well as their respective members of parliaments. Regarding its implementation, the majority of Indonesian Muslim scholars have accepted the concept of democracy positively considering its compatibility with the Islamic teachings (Hakiki, 2016: 1-17). Regarding the corruption phenomenon, the Transparency International mentions that Indonesia's Corruption Perception Index (CPI) score rose to 38 , and the country ranked the $89^{\text {th }}$ out of all countries in the world in 2018. Here, the Zero Point denotes the most corrupt country; the higher the rank of a country, the less corruption is found in the country (Saputra, 2019).

Life and health insurances have also been part of public needs and interests. Therefore, practicing them in a way which is in line with the Islamic law must be studied and, in turn, stipulated under the government regulations (Hasanah, 2019: 239-268). Similarly, the practice of human organ transplantation, including the recent breakthrough in medical treatment, stem cell therapy, need to be taken into account as well (Setiawan, 2014). These are a few examples of contemporary issues in today's human life, where an up-to-date perspective of Islamic law must be present.

Questioning maqāsid al-sharíat is essentially considered as a 
perennial issue with great questions; Is the Islamic law eternal or temporary? Is it adaptable to changes and modernization? Can it answer different and new issues that arise among society? And Is it capable of accommodating the changes and the process of modernization? among others. There are also a series of other questions closely related to the maquasid al-sharíat issues. To this end, discussing and elaborating the issues has been relevant to this date.

Addressing the characteristics of Islamic law, two groups of scholars have different opinions. The first group, comprising of some fuqahä (Islamic jurists) and several Islamologists, concludes that the Islamic law is eternal. Here, C. S. Hurgonje (2010) and Joseph Schacht (1996: 1) belong to this group. They claim, in accordance with its concept, development and methodology, the Islamic law is eternal. Consequently, it is not adaptable to any form of social changes and process of modernization (Masood, 1998). They build their claim based on the following premises: First, the Islamic law is eternal as the concept of law is authoritative, divine and absolute, which in turn does not allow any change in it. As a logical consequence of this concept is that the law is sacred, final, and eternal and closes any door to changes. Second, the Islamic law is eternal due to the nature of its origin and development, in which it was untouched by any institution of law and social changes during its formative period. Third, Islamic law is eternal as it does not develop any methodology for its changes.

In contrast, the second group says Islamic law can adapt to social changes and modernization. This group includes the majority of fuqahā (Islamic jurists), Subhi Mahmasani (Mahmashani, 1981), for example, and a small number of Islamic law observers including Linant Bellefond (1956: 412-425) and Coulson (2011: 81). They argue the principles of the Islamic law that depends on maslahat (public interests), maqūsid al-sharī'at (the objectives of Islamic law), and the flexibility of law in practice, as well as Ijtihäd (independent reasoning) (Arief, 2017) clearly show that the Islamic law is adaptable to social changes and modernization. They construct their arguments rationally. According to this group, Islamic law aims at giving benefits to all human beings. Therefore, it is expected that the Islamic law appreciate and welcome every social change and modernization for 
they considerably take parts in making efforts to achieve the maquasid al-sharíat (the objectives of Islamic law). Given its objectives, Islamic law must be flexible.

Acknowledged or not, the interaction between social changes and the theory of Islamic law has taken place since the time of Prophet Muhammad (Peace be Upon Him). This interaction reached its peak during the time of the enculturation between the Islamic and the Western cultures. This is a logical consequence of the expansion efforts during the reign of the Rashidun Caliphs, Umayyad caliphate, and Abbasid caliphate. Consequently, the renewal of Islamic law has occurred in terms of codification and modification. This renewal or modernization that has taken place in the body of Islamic law is based on the concepts of maslahat (public interest) and maquasid al-aḅamm (the objectives of rulings) (Halaq, 2005; Bsoul, 2016; Thahir, 2019).

Al-Shațibi wrote a mature concept of maqūsid al-sharīat in his book al-Muwāfaqāt fì Ușūl al-Sharī'at, (al-Shațībī and Daraz) 'Allal al-Fassi in Maqūsid al-Sharī'at al-Islāmiyyat wa Makārimuhā, (al-Fasi, 1993) and Ibn 'Āshūr in Maqūsid al-sharī'at al-Islämiyyah respectively (Zed, 2008). They, among others, are regarded as maqūsid al-sharīat initiators. To name a few, the contemporary Muslim scholars with their works on maqūsid al-sharīat include Abd al-Wahhāb Khallāf, al-Raisūnī, Sayyid Quṭb, Yūsuf al-Qaraḍāwī, and Jasser Auda.

This study aims at elaborating the position of maquasid alshari'at as the main reference and ethical-spiritual foundation for the dynamization process of Islamic law in dealing with contemporary issues. This study also examines the concept of maquasid al-shari'at and analyzes the flexibility, adaptability, and dynamic of Islamic law. This is library research (Zed, 2008) in which its sources of data are literature, a collection of written works. In term of the data collection, this study uses a documentary technique (Creswell, 2014; Nawawi, 1991: 133). According to Bailey, a documentary technique refers to analyzing documents that contain information about the phenomenon expected to study (Bailey, 2007). According to Payne and Payne, this method is used to investigate and classify physical sources, most commonly written documents, in the private or public domain (Payne and Payne, 2004). Hadari Nawawi mentions that a documentary technique is a technique of collecting data through written heritages 
- especially in terms of archives and books - about opinions, theories, and arguments regarding the problems being studied (Nawawi). Here, this study conducts an in-depth study on some works (i.e. books) of previous Muslim scholars focusing on maquasid al-sharīat including, but not limited to, al-Shațībīs Al-Muwāfaqàt fì Ușūl al-Sharīat, al-Fassi's Maqāsid al-sharī'at al-Islämiyyat wa Makārimuhā, and Ibnu 'Ashur's Maqūsid al-sharīat al-Islämiyyat respectively. It also reviews the works of contemporary scholars: Masāadir al-Tashrī' al-Islämī fì mā là Nașs\} fìh by Abd al-Wahhāb Khallāf, Naz\}ariyyat al-Maqūsid 'ind al-Imām al-Shațībi by Ahmad al-Raishuni, Al-Adälat al-Ijtimäiryyat fì al-Islām by Sayyid Quṭb, Al-Ijtihād fì al-Sharīat al-Islämiyyah ma’a Nazrāti Tahlīliyyāt fì al-Ijtihād al-Mu'āṣir by Yūsuf al-Qaraḍ̄āī, and Maqashid Shariah as Philosophy of Islamic Law: A Systems Approach by Jasser Auda. Other works in terms of books, articles, and journals are also used to gain a better understanding of the maquasid al-sharíat.

To analyze the data in this study, the following procedures are applied: 1) capturing the basic ideas of the primary sources, 2) highlighting the ideas through the research method perspective, 3) presenting various views and theories in secondary sources to sharpen and complete the analysis, and 4) performing further analysis to develop a new analysis which is in line with the ideas. By conducting the last procedure, this study is expected to produce objective findings and conclusion.

\section{Discussion}

\section{Understanding the Roles of Human Beings}

According to Hasan al-Turabi, the preservation of the earth has something to do with human existence. For this reason, saving the human species from extinction is necessary (1975: 75). One of the ways to save them is by allowing them to live in pairs, a man and a woman, to have descendants (tawallud) and to breed (tanäsul). Here, human souls need proper and effective regulations since damaged human souls will cause damages on earth (Junaidi, 2014: 71).

Islam teaches universal norms stating that everyone is a part of and has a responsibility to others. They are a part of nature and universal humanity. Therefore, they cannot escape from others and need to live in groups to defend themselves, to breed, and to carry 
out more comprehensive functions to fulfil their tasks of being Allah's vicegerents (Junaidi, 2014: 71). The smallest society is family, and it joins with other families to form a community. In turn, lots of communities form a large group of people which is known as a nation or a state. Everyone has different status according to their role in life. This is what encourages each of people to support one another; the weak and vulnerable are protected, and the rich can benefit from the poor. Human beings are weak creatures as Allah said in Sūrat al-Nisā‘ [4]: 28 (Ali, 1992: 193). They are unable to fulfill their own needs as they must complement and support one another. In other words, they depend on other creatures in this world (al-Tabarī, 2000: 32).

Islam also teaches that all human beings are brothers and sisters since they come from one ancestor, the Prophet Adam, as mentioned in Sūrat al-Nisā' [4]: 1 (Ali, 1992: 183). Allah then created Eve from Adam as his wife. From them come all human beings in this world. During his last pilgrimage, Prophet Muhammad gave his farewell sermon. Among others, he said, "O people, know that your God is one, your ancestors are one. Do know there are no privilege for Arabs over Ajam (non-Arab) people and neither do Ajam over Arabs. White people have no superiority over black people, and neither do black people over white people except for their fear of Allah." (Hanbal, 1978).

His sermon becomes an essential principle that all human beings are created equal. Ethnic, linguistic, and skin color differences due to geographical factors are only signs to make it easier to recognize them and provide help as mentioned in Sūrat Al-Hujurāt [49]: 13: "Indeed, the noblest person in Allah's side is the most pious. Men and women only differ in gender. Their deeds are judged and justified by their piety and their ability to give more benefits for others." (Ali, 1992: 1342-1343).

\section{The Islamic Law at a Glance}

Throughout human history, a social change over time is a natural phenomenon. No society is in a dormant state at different times; all is always moving and heading towards an increasingly perfect civilization (Junaidi, 2014: 67). To realize such noble mission of creating a perfect civilization and fulfilling Allah's order to become His vicegerents and preserve the earth, proper and effective regulations to rule their life is necessary. Allah has established such regulations through the teachings 
delivered by all of His Messengers. For Muslims, the regulations are written in Islamic law, which is different from other laws as previously mentioned.

The Islamic law is different and is exceptional compared to other laws for several reasons; 1) the Islamic law has benefits and effects which are not only limited to one's life in the present time in this world, but also in the hereafter. This is because the law itself is created for happiness in both dimensions, the present and the afterlives; 2) the benefits brought by the Islamic law are not only related to material dimension $(m \bar{a} d d \bar{\imath})$ but also immaterial dimension (rühì), and 3) the religious benefits in the Islamic law become the foundation for other laws. This means if a religious benefit in the Islamic law contradicts to the one which belongs to the other laws, the religious benefit must come first (Bakrie: 64; Sya'bani, 130).

Islamic law is a law which is closely related to this change. Besides playing a role in changing society from its bad condition to a good one, the Islamic law itself has also been a product of change as the result of contextual Ijtihäd by its scholars and practitioners from the time of Prophet Muhammad to the present day (al-Awwa, 1998: 4). During the Prophet's days, religious issues were solved through revelation, whereas worldly issues were settled through consultation with his Companions. In the era of the Companions, nașs (texts) from the Qurān and Hadīth became the primary reference, but the policies and decisions were made through discussions and deliberations among them.

In responding to the contemporary issues, Islamic law has been more developed than its initial inspiration. However, the law still refers to the texts in the Qur'an and Sunnat as its primary sources. In this regard, the Islamic law is not an instant law made by God according to His desires. Still, it is the law that will progressively develop and guide the development of Muslim society through Ijtihäd (independent reasoning). The Ijtihād is conducted by understanding the texts, analogizing new cases to the ones that already have legal rules, and issuing new laws in line with the objectives of shari'at (Madkur, 1983: 58-62).

According to Anwar, the process of legal reasoning in stipulating a legal regulation involves three poles which have dialectical relations 
to one another. These three include the texts, the reality, and the objectives of the law. The texts, with their symbols and dependence on generalization and abstraction in expressing an object, enable the mujtahid (the one who conducts Ijtihäd) to add a new meaning to them. This meaning is produced to adequately understand the issues and the spatio-temporal space in which it happens and to consider the objectives of law. The reality of the issues lights up the understanding of the texts, while the texts give a clear orientation in coping with reality at the same time (Anwar, 2003: 154).

One's dependency on Islamic law can bring glory as the law has an ability to shape human beings into perfect beings or make them more humane. In its realization, the Islamic law includes 2 (two) categories: sharíat which is permanent, clear, firm, qațiy (absolute) and universally applicable; and figh which is open to changes and interpretable. Here, the mujtahid plays a significant role in finding the truth based on their independent reasoning. For this reason, the truth is zanniy (interpretable) and supposedly applicable. The latter category is flexible, adaptable and responsive to the social dynamics and the changing times. With such natures, Islamic law can provide reasonable and applicable solutions (Junaidi, 2014: 77).

The Qur'ān is the primary source of Islamic law. However, according to Wahyuni, not all of the texts contain and give an understanding which is quțiy al-dilälah (in a strict, specific, and detailed manner) and no longer requires a detailed explanation. There are a lot of verses in the Qur'ān with mujmal (global/undetailed), khafì (unclear), or mushkil (abstruse) narration. In many cases, the Qur'ān even only mentions universal norms and values. To understand such verses would undoubtedly require further explanation and details. However, it does not mean the imperfection or weakness of the Qur'ān, but it is an advantage that makes it to be always up to date and relevant to every place and era and in line with its position as the source of the sharia (Wahyuni, 2016: 225-252).

The Islamic law which has been practiced until now is a dynamic law stipulated by Muslims based on their understanding and interpretation on the revelation (texts) (ibn Khaldun, 200). Such understanding and interpretation, which is adaptable and adjustable to the changing times, is called fiqh. Here, fiqh is known as al-hukm 
al-Isläm (Islamic law). The term al-ḥukm al-Isläm distinguishes it from other laws. Such term is not popular in the books of ușul fiqh, and it is only mentioned once by Ibn Hazm al-Zāhirī in al-Nubzat alKäfiyah, Volume I, on page 59. Besides, it is mentioned three times in al-Furüq, a book written by As'ad ibn Muhammad ibn al-Husayn. In the work of Muhammad ibn Bahādur al-Zarkashi, al-Manthūr fì al-Qawāid, it is only mentioned once (Junaidi, 2014: 18).

The term al-ḩukm al-Isläm is often understood and interpreted as figh and al-shari'at al-Islämiyyah. However, each of these terms has its framework. For this reason, in several posts and forums, contemporary Muslim scholars make extra efforts to describe each term so that they can be distinguished from one another and have a respective proportional position (Khatib, 2014: 79-80).

The method of conducting istinbät (searching for legal cause) in usül fiqh (the principles of Islamic Jurisprudence) is classified into three forms: tarīqat al-Ijtihād al-bayāni (a semantic/linguistic Ijtihād method), țariqat al-ijtihäd al-tawfíqi (reasoning towards conflicting religious propositions), and tarīqat al-ijtihäd al-ta'lìli (reasoning with legal causes/purposes), one of which is the method of maqasid alsharíat (Anwar, 2003: 157). This method is developed to achieve the ultimate objective in establishing and implementing Islamic law, benefits for humanity.

Tarīqat al-ijtihād al-bayāni is an Ijtihäd method or legal discovery by explaining the existing naș (texts) through linguistic/semantic reasoning or approaches to the texts. The followings are the procedures of this method: 1) checking on the clarity of the statements mentioned in the texts (Qur'ān and Hadìth), 2) finding the meaning of the texts, 3) observing the scope (broadness and narrowness) of the statements mentioned in the texts, and 4) analyzing the forms of taklif (a legal charge or obligation) mentioned in the texts (Anwar, 2003: 157-158).

In the meantime, tariqah al-ijtihäd al-tawfíqi is a method of making law by harmonizing the conflicting texts in the Qur'ān and the Hadīth. This method of ijtihad is carried out in three techniques; aljam’u (compromising), al-Naskh (abrogation), and at-tarjīh (reinforcing) (Anwar, 2003: 158). Lastly, țariqat al-ijtihäd al-ta'lili is a legal discovery method by finding the legal causes or purposes mentioned in the texts in the Qur'ān and the Hadìth. This ta'lìli method is classified 
into two types; ta'ililu al-ahkām bi al-illah (legal discovery based on legal causes) and ta'lìlu al-aḥkām bi maqāsidi al-sharīat (legal discovery based on legal purposes) (Anwar, 2003: 158).

According to Hazri, the maqāsid is supposed to give way for the usül al-figh for the ușull has been occupied with technicalities. Any difficulties are expected to be solved or dealt with by discovering the underlying objectives of the shari'at. Here, the historical look at the development of Islamic law has revealed the constitution of ijtihad (Hazri, 2015: 422-426).

\section{Understanding Maqāṣid al-Sharīat}

The term maqșid (plural: maqūsid) means a purpose, a principle, an objective, an intent, an end, a goal, telos (Greek), finalité (French), or Zweck (German) (Auda, 2008: 2).

It derives from the verb qașada-yaqșudu and has different meanings, i.e. leading to one direction, goal, middle-path, fairness, consistency, not exceeding limits, straight path, a middle-way between exaggeration and insufficiency. In the meantime, the word shari'at, according to Thahir, etymologically means al-utbah (the lap of the valley), al-atabah (a doorway and a stair), mawrid al-shariah (a path where the thirsty look for water), and al-tariq al-mustaqimat (a straight path). The use of the term shariah referring to the meaning mawrid al-sharíat is found in the words of the Arabs: shara'at al-ibil, which means a camel goes out and heads to the water source to drink (Ismai'il, 1985; Musa, 1989: 17), whereas its meaning as tariqat al-mustaqimat is mentioned in Sūrat al-Jāthiyah [45]: 18: "Then We put thee on the (right) way of religion; so follow thou that (way), and follow not the desires of those who know not" (Ali, 1992: 1297)

For Muslims, sharīat means religion, al-țaìqat al-mustaqimat (the straight path), and al-nusus al-muqaddas (the sacred texts) from the Qur'ān and Sunnat (Rauf, 1989: 1-50). Schacht says, sharíat is the sacred law of Islam. He adds, it is an all-embracing body of religious duties, the totality of Allah's commands that regulate the life of every Muslim in all aspects; it consists of ordinances regarding worship and rituals, as well as political and (in the narrow sense) legal rules." (2007: 142). In short, maquasid al-sharī'at is defined as the objectives or purposes behind the Islamic law enactment (Auda, 2008: 2). 
The knowledge of maqușid al-sharī'at is essential. Here, understanding the maqūsid al-shari'at can be used as a tool to comprehend narratives in the Holy Qur'ān and the Sunnat/Hadìth. It also helps to settle the conflicting arguments (ta'ärud al-dilālah) that may be found in both sources of Islamic law. Further, it can also be used as a method to establish a law in cases where legal provisions are not available either in the Qur'an or the Sunnat (Sya'bani, 138: 138).

In ușül al-fiqh, the objectives or purposes of Islamic law are often referred to as maquasid al-sharīat which is manifested or reflected through the five fundamental elements in the Islamic law: hifz al-din (protection and preservation of religion), hifz al-aql (protection and preservation of intellect), hifz al-nafs (protection and preservation of soul), hifz al-mal (protection and preservation of property), and hifz al-'irdh (protection and preservation of lineage). Maquasid al-sharī'at is also mentioned in different terms, including maqūsid al-sharì, maqāsid al-sharīat, and al-maqūsid al-shar'iyyah (Raosuni, 1992: 17). Essentially, these different terms imply the same meaning, which is the purposes or objectives of Islamic law enactment. In general, the Muslim scholars of Islamic jurisprudence interpret maqūsid sharīat as the essence of the Islamic law enactment (al-Fasi, 1993). Najm al-Din al-T\{üfī (d. $716 \mathrm{H} / \mathrm{1216}$ ), for example, defines maslahat as what fulfills Allah's purpose as the Law Maker (al-Shāri). Meanwhile, al-Qarafì (d. 1285 $\mathrm{H} / 1868$ ) associates maslahat and maquasid with the principles of Islamic Jurisprudence. He states 'A purpose of the law (i.e. maqāsid al-shari'at) is invalid unless it gives benefits or avoids harms' (al-Qarafi, 1994: 33). Al-Fasi, as quoted by al-Raisūnī, mentions:

"Maqūsid al-shari'at is the objectives of shari'at and the secrets that have been set by al-Shäri' (Allah) in any provisions of His law" (al-Rausani, 1992: 18).

The general principle of maqūsid al-sharīat is enforcing the significance of jalb al-masāliḥ wa dar' al-mafäsid (getting benefits and avoiding harms). In this case, al-Raisuni states:

"In general, maqāsid means upholding rules, getting benefits, avoiding harms, building equality among human beings and establishing sharīat (the Islamic law) as an authoritative legal product. On the other hand, it can also lead Muslim to become a strong, respectable and calming community. Suffice to say, maquasid al-shari'at is the objectives of the 
Islamic law enactment which needs to happen for the sake of human beings as a whole" (al-Rausani, 1992: 18-19).

\section{A Brief History of Maqāsid al-Sharīat}

The literature review shows that the maquasid al-shari'at in terms of maslahat or any other terms having a close meaning with maqāsid has essentially been present since the time of Prophet Muhammad (Peace be Upon Him) and his Companions, especially 'Umar ibn Khattab and the other caliphs (i.e. Abu Bakr, 'Uthman and 'Ali), as narrated in several events. This is because the shari'at brought by Prophet Muhammad (Peace be Upon Him) to give benefits to all human beings is not supposed to be understood textually. Such benefits have existed since the Qur'ān verses were revealed and have also been mentioned in the hadīth. This indicates that maqūsid al-sharī'at basically never leaves the texts but always goes along with it (Hasan, 209).

One of the most popular examples is mentioned in a mutawätir (mass transmitted) hadīth about performing 'Asr prayer in Banī Quraizat (Auda, 2008). Prophet Muhammad (Peace be Upon Him) sent some of his companions to Banī Quraizat to ask them to perform 'Asr prayer (al Bukhari, 1986: 321). However, the usual time for performing 'Asr prayer was almost over, yet they had not arrived in Banī Quraizat area. At the time, the Companions were divided into two groups with two different opinions. The first group argued for performing the Asr' prayer in Banī Quraizat area with any consequences, while the second insisted on performing the prayer on the way before the 'Asr prayer time ran out.

The argument behind the first opinion is that the Prophet's command literally asked everyone to perform the 'Asr prayer in Banī Quraizat area. In the meantime, the second opinion is based on the objective or purpose mentioned in the Prophet's command, which was to ask the Companions to rush into Banī Quraizat area. It was not intended to postpone the 'Asr prayer until the time was over. According to the narrators of the hadith, when the Companions reported the incidence to the Prophet, the Prophet (Peace be Upon Him) confirmed and justified the two opinions. The Prophet's taqrir (acknowledgement), as later practiced by Islamic jurists and scholars, shows the possibility and permission to have different points of view (Isra, 2018). 
The only scholar who disagreed with the opinion of the Companions who performed the Asr' prayer on their way to Bani Quraizah is Ibn Hazm al-Zahiri (a prominent jurist of the Zahiri school). He argued that those Companions should have performed the 'Asr prayer after arriving at Banī Quraizat as told by the Prophet even though they did it after midnight (Ibnu Hazam, 29). The above example illustrates an early history of the concept of maqussid al-sharí'at in implementing the Islamic law and the arising implications from giving the fundamental position on the maqāsid which has existed even at the times of the Prophet and his Companions.

The Quran, as the transcendental source of Islamic teachings, provides an essential foundation, the principle of governing the interest of people in every enactment of its legal regulation (Hallaq, 2005, 84). One of the shreds of evidence showing the presence of maqasid or maslahat in every law enactment and texts is that the texts only mention the basic principles in the application of practical laws; civic, crime, economics, politics, and any other aspects. In some verses in the Qur'ān, the law on a matter is mentioned along with its wisdom, explicitly or implicitly, The examples are the verse about gambling and wine (Ali, 1992: 277), the verse about alms or charity (Ali, 1992: 468 ), and the verse about women's menstruation, among others (Ali, 1992: 89-90). This shows the importance of seeking benefits in the objectives of law which have become the fundamental principle of Islamic law. Many texts in the Quran only state the general principles of law; al-așlu fìl-ashyä al-ibāhat hattā yadull al-dalīl 'alā al-tahrīm (permissibility is the fundamental norm in all things unless there is evidence to establish a prohibition) (Ali, 1992: 23), the verse on the fundamental of law enforcement about raf' al-haraj wa al-taysir (avoiding difficulties and promoting simplicities) (68-69), and the verse about performing obligations and giving rights to their owners, among others (Hasan, 2019).

During the era of the Prophet's Companions, the need for maquạid was more pressing. This happened since a lot of issues needed definitive legal answers considering many Companions were in different places, especially after the expansion of Islam. They found customs and cultures in one place were different from the ones in another. Consequently, they, as warathah al-anbiya (the heirs of the 
Prophets) played a significant role in continuing the Prophet's duty to spread Islam. They had been trained well since they accompanied the Prophet during their lifetime. No wonder if they could have a powerful potential in capturing and applying maqūsid in every process of conducting Ijtihäd.

The implementation of maqussid shariah during their era is found in many occasions: electing Abu Bakar as the first caliph; forbidding Abu Bakar from conducting business due to his public position by allocating some wages for him in return; not executing the penalty of cutting off the thieves' hands during the prolonged drought; (Khasan, 2008 296-314; Amir, 1987) and so on. In formulating the rules of life for Muslims at the time, they referred to the texts in the Quran and the hadith of the Prophet. If they did not find any from both, the one that could correspond to the existing issues, they then conducted Ijtihäd by looking for the lessons mentioned in the Quràn and the hadiths.

One of the issues that arose after the Prophet Muhammad passed away is Hudhaifa's marriage to a Jewish woman. 'Umar bin Khattab, who heard the information, asked him to divorce her. Since Hudhaifat knew that marrying a woman of the book was allowed, he asked 'Umar if the woman was haräm (unlawful) for him. 'Umar then replied that it was not haräm to marry a woman of the book. However, he was worried that other Companions would follow his step as Jewish women generally had a more beautiful appearance. If that happened, it could cause a slander for Muslim women and lead to pre-marital sex among society as there would be a large number of unmarried Muslim women (Hasan, 2019).

Just like the Companions, täbi in (the generation right after the Companions) always associated the implementation of the Islamic law to maqāsid. This is because they learned and followed the methods directly from the Companions. If they did not find any texts regarding a specific issue, they would consider mașlahat (benefits) and qiyass (analogy). As Ibrahim an-Nakha'i once said, "Allah's laws surely have a purpose which is al-hikmat (wisdom) and maslahat (benefit) that returns to us" (ibn Ali ibn Hajar al Asqalani, 1995). The pattern of maqāsid during the täbiin era is reflected by two strong schools, the Hejaz and Iraq schools. They have both practiced the fundamentals of maslahat in 
producing legal decisions. In addition, different circumstances between the era of the Companions and that of täbiìn encourage the latter to perform istinbāt (searching for legal cause) with any means of maslahat.

A clear example is the issue of tasì (setting up a price as a general benchmark) when prices rise, and demands increase. The täbiìn including Sa'id bin al-Musayyab, Rabi'ah bin Abdul Rahman, and others issued a fatwā (religious advice) that tas'ì is permissible. The Prophet (Peace be Upon Him) himself was reluctant to set up a fixed price even at the time when prices rose since tasiz contains elements of unwillingness from the capital owners. However, the tabiin clarified that the contexts that occurred at the time of the Prophet (Peace be Upon Him) and what happened in their time are different. They added that the rising prices of daily necessities during the time of the Prophet (Peace be Upon Him) were triggered by changes in the natural conditions due to the prolonged drought. In other words, the issue was not pressing at the time. In the context of the tabiin era, the increasing price was triggered by the spread of stockpiling, greediness, and weak religious capacity. For this reason, such a condition requires the regulation of general pricing to maintain balance and avoid hoarding practices. These two examples are frequently mentioned in the books of hadith, including Ibn Majah's Sunan and Imam Malik's Al-Muwatta' and become an essential discussion in the classical and contemporary fiqh books (Hasan, 2009).

Conducting such method in making a decision on a new issue, after the death of the Prophet (Peace be Upon Him), by referring to the texts in the Qur'an and hadīth and upholding the maquasid shariah essentially has tarted from the era of the Companions, täbi'in, tāabi al-tābi ìn (the generation right after täbi ìn), the imam of madhähib (schools of Islamic law), and so on, to this present time.

In view of the al-a'immat al-mujtahidin (the imäms of Ijtihäd), the maqūsid can essentially be found in the methodology of their istinbāt. In Maliki's school, for instance, fiqh masăliḥ (jurisprudence based on benefits) is very popular for the results of the jurisprudence are dominated with the principle of achieving benefits. In the meantime, Imam Abu Hanifah generated maqūsid through qiyās, istihssān and urf. Similarly, Imam Shafi'i also applied qiyās while Imam Ahmad ibn Hanbal and Imam Malik went with qiyās, masālih mursalah, shadd 
al-dharīah, and fath al-dhari'ah. In short, all scholars of the majority schools have agreed to use maqāsid syaríah as a legal foundation except the Zahiriyyah school that only refer to the texts in the Qur'ān and the Hadith. For this reason, they have denied the presence of ta' lil and qiyās. Nevertheless, they have applied maquasid on a limited basis to those which are only mentioned by the texts (Nur, 2008).

The study conducted by Ahmad al-Raisūnī mentions that the first person used the term maqāsid al-shar'îy is Abu al-Ma'ali Abd al-Malik Ibn Abdullah Imam al-Haramain al-Juwaynī, (d. $478 \mathrm{H} / 1085$ ) in his book al-Burhān fi Ușül al-Fiqh (al Juwayni, 1980). The book is also known as al-Kulliyyah al-Khams and al-Usül al-Sharīat (al-Raisūnī, 1992: 38). According to the works of previous Muslim scholars, Imam al-Shatibi illustrates and draws a conclusion that all scholars agree that Allah has established various legal provisions to maintain the five fundamental elements (al-daruriyyat al-khams) in the Islamic law: hifz al-din (protection and preservation of religion), hifz al-aql (protection and preservation of intellect), hifz al-nafs (protection and preservation of soul), hifz al-mal (protection and preservation of property), and hifz al-irdh (protection and preservation of lineage). These five elements are also known as the objectives of the Islamic law (al-maquasid alshar'ïyah) (al-Raisūnī, 1992: 39) while Imam al-Ghazālī has used the term al-usūl al-khamsah (2018: 286-287) Al-Ghazalī then claims anything which is aimed at maintaining the five fundamental elements is considered as al-maslahat. In contrast, anything contradicts to them is regarded as an opponent of the al-maslahat, which is al-mafsadah (harms). Avoiding mafsadah itself is also considered as al-maslahat (al Ghazali, 2018: 286-287).

Tāj al-Dīn 'Abd al-Wahhab Ibn al-Subkī, who was usually called as Imam al-Subkī (d. $771 \mathrm{H} /$ 1370), adds one more objective of law, protection and preservation of dignity (hifz al-ird). It is then commonly known as al-kulliyyah al-sittah (ibn al-Subkī: 280). AlQarafi (d. 694 H/ 1295) is actually the first Muslim scholar who started using such term and classified it into the fifth objective (i.e. hifz al-mallprotection and preservation of property) (al-Qarafi, 1973: 391). In the same way, a contemporary scholar, Sảid Ramaḍan al-Būṭī, also mentions that the objective of shari'at is to preserve one's religion, soul, intellect, lineage, and property (al-Būṭī, 1990: 27). 
Muslim scholars have also agreed that the scale of priority in implementing the Islamic law is in line with the order of the protection and preservation of the five fundamental elements. This means protecting one's religion takes precedence over protecting one's life, protecting one's life takes precedence over protecting one's intellect, and so on. In short, some scholars divide the objectives of the Islamic law into five fundamental elements and some others classify them into six elements. Some do not even develop them in details.

The Maqūsid shariah proposed by al-Shațîīi (al-Shațîīi and Daraz, 1999) is basically a follow-up of the concept of maslahat that have emerged in the majority works of ușul fiqh experts before him. In other words, the embryo or gene of maqussid shariah has existed since the time of Prophet Muhammad (Peace be Upon Him) and the era of his Companions. Ibn 'Ashūr states that the validity of the concept of maquasid as a tool for legal formulation lies on the extent of its certainty and closeness to the level of qat $\bar{\imath} \bar{i}$ (certain) (Ibnu Ashur). For this reason, the concept of maquasid al-sharíat he offers stands upright and he dared to make a valuable breakthrough and contribution to the next generation in studying and formulating the maqūsid al-shari' $a t$ on this basis.

His statement has been supported by a historical, systematical, and periodical reviews starting from the times of the Prophet, the Companions, the täbiin the mujtahidin and those who were closest to the time of al-Shațibì. It has gone further until the present day with the emergence of contemporary scholars including Abd al-Wahhab Khallaf, Ahmad al-Raisūnī, Yūsuf al-Qaraḍāwī, and Jasser Auda, to name a few. The literature review shows that maslahat has been the essence of maqūsid shariah.

\section{Shari' ${ }^{-} a t$ as the Main Reference and Ethical-Spiritual Foundation for the Dynamization Process of Islamic Law}

The contemporary Ijtihäd (independent reasoning) has become a primary requirement. Al-Qaradawi even claims that its status reaches fardu kifäyah (a collective obligation) (al-Qardhawi, 1994: 34) especially in the today's era with its dynamic problems and rapid technological advances. The old and classic methods and approaches will experience difficulties in providing legal solution to deal with 
contemporary cases. Therefore, finding the right and sophisticated method in Ijtihäd to compete with the progressive development of society and the dynamics of the demanding era is necessary. In this regard, the method of maqāsid al-shari'at is considered capable of interacting with and counterbalancing the progress of contemporary era (Sapriadi, 2018: 1-2).

Every Allah's law has its objectives, both special objectives ('illät and hikmat) and general objectives (maquasid 'ämmat). All is to give benefits to human beings. Any law which generally aims at giving benefits means realizing the maqūsid al-sharīat. Here, the flexibility, versatility, and dynamics of the Islamic law appear in the concept of maquasid al-sharíat. At the same time, the concept also opens the mind of those who claim that Islamic law is so immutable, doctrinal, eternal, and final that it is assumed to be inadaptable to various forms of social changes and modernization which bring lots of contemporary issues.

Referring to the progress and development of the maquạid from time to time, the maqāsid has a very significant position in the process of Ijtihäd. It is supported by many texts, theorems, logic and realities that are present and aim at giving benefits to human beings, not only in this world, but also in the hereafter. In fact, to acknowledge that the dimension of maqassid in the study of Islamic law is very significant, a number of scholars of Islamic Jurisprudence place it as one of the main requirements to perform Ijtihād. Al-Raisūnī claims:

'For the first time and within certain and observable limits, we have found the first requirement to conduct Ijtihäd is to understand the maquassid al-sharíat properly. In addition, we have also discovered the second and last requirement inseparable from understanding the maquasid that is the possibility of performing istinbatt of the Islamic law by understanding the maquasid al-sharíat.'(al-Rausani, 1992: 353).

The understanding of the objectives of Islamic law is to avoiding a condition where a person who interpret or conduct reasoning on Islamic law gets trapped in the laws which are particular (juziyyāt) and ignores the maqūsid al-sharī'at. In this regard, al-Qaradāwī (1985: 44) declares:

'Understanding the objectives of Islamic law (maquassid al-sharīat) is so necessary that one does not get caught up in a mistake by only paying attention to the laws which are partial $\left(j u z^{\hat{\imath}}\right)$, without addressing the 
objectives of laws, universal (kullì) in nature. Otherwise, the law will only lead (us) to a mix-up and confusion.'

As a method, the maqūsid al-sharīat gives a perspective on reasoning in solving any issues in Islamic law, particularly regarding mu'ämalah (transaction) in the religious life of plural societies. To finally reach and make an effort to solve the issues, a mujtahid must first focus his/her attention on the objective of law (maquasid) mentioned in the Quran and the hadith. This means they do not merely see the texts literally, but preferably the objectives of the law itself as the main point. In this case, to find and formulate ideally legal ethics and morals mentioned in the verses is the most important thing (Ghazali, 2005: 359). In other words, the maqāsid al-sharíat or ideally legal ethics are explored and given more attention when establishing or making legal products, whether they are explicitly mentioned in the texts or in the context of the texts. Here, the context is not personal context which is particular (juz'i), but rather universal context (kulli).

Further, performing istinbāt is not merely observing the asbāb alnuzul (the occasions of revelation) of a text in its normative sense, but more importantly on its maqāsid al-sharīat (Ghazali, 2005: 359). The use of maqāsid is emphasized and manifested through the expression al-ibrah bi al-maqāsid là bi al-alfäz (what to consider is the maqāsid, not the texts literally) (Ghazali, 2005: 359). To this end, what to consider from a statement mentioned in the texts in the Quran and the hadith is the generality of the objective of $\operatorname{sharí}^{-} a t$ and such consideration should be separated from any specific nașs (texts).

To accommodate contemporary issues, the perspective of understanding the maqāsid as a method to establish the Islamic law is to know, to search, and to gain the basic principles of Islam. Therefore, when a law has come to its maqāsid, the texts must be inseparable from their initial Arab context (i.e. decontextualizing the texts) and re-contextualization is, in turn, made to associate the basic principles of Islam into the non-Arabic context. In the end, the contextualization, discontextualization, and re-contextualization become the interpretation techniques that can be applied over time (Ghazali, 2005: 359).

As an answer, performing a new interpretation on the approaches of studying religious texts, especially the texts produced by Islamic 
scholars, is likely to take place. Among the new interpretations is to present an understanding that emphasizes on the objectives of the legal enactment itself or the maqūsid al-sharīat. Therefore, developing an understanding that focuses on the substances instead of the legalformalism of the naș (texts) is necessary. Abdul Moqsith states "In searching for maquasid al-sharīat by various means, one is not supposed to be enthralled by the beauty of a text. This is because being enthralled is an ideological act that will only dull their creativity in searching for the objective meaning and the importance of understanding the background or the occasions of revelation" (Ghazali, 2005: 361). Finding the substantive meaning will accordingly shape and analysis not only on the structure of sentences, but also - what is rather foundational- the social and cultural classes and structures that surround the history of the birth of texts.

The Islamic law has no other objective but to bring benefits (jalb al-mașälih) and avoid any harms (dariu al-mafäsid). This paradigm is constructed by al-Thūfĩ in Risälah fi Riāyah al-Mașlahat. He mentions "idhā ta'arada al-naș wa al-mașlahatu arjahā al-mașlahat" (if a text and maslahat contradict to one another, maslahat will take precedence) (Khallaf, 1982). Referring to this paradigm, maslahat may revoke the texts in the Quran or the Hadith. This means the reasoning on maslahat can become a stronger argument than the one on the texts (nass).

In this regard, individual (subjective) maslahat and universal (collective) maslahat must first be separated. An individual (subjective) maslahat, for instance, is associated with individual interests which are separated from the interests of others. As it is subjective in nature, the one entitled to determine it is the individuals concerned (Khallaf, 1982: 362). In the meantime, the maslahat that has social-objective nature for the interest of many people is authorized and assessed by groups of people through a shiurā (deliberation) to reach a consensus $(i j m \vec{a})$. In turn, the decision that has become the result of the consensus by considering the maslahat serves as a binding supreme law.

Maslahat (benefit), as the realization of maqașid, is the basic foundation of any legislation in Islamic law. Practically, this does not happen because the Islamic teachings need to follow and adapt to the development of maslahat, but to objectively gain mașlahat. Adaptation is required. For this reason, maslahat is a fundamental, unchanged, and 
universal religious teaching, In the meantime, the practice to gain the ideal maslahat is a religious case which is classified as fus ül (branches). Such case can change due to the changing times and civilizations.

The maslahat or maqūsid al-shari'at itself serves as the main reference and ethical-spiritual foundation for the dynamization process of the Islamic law in dealing with contemporary issues. Due to the institutionalized and developed concept of maqāsid al-sharīat, further question, whether the maqüsid can become an independent legitimacy, has emerged.

In responding to such question, three groups have different opinions. The first group sees the maqūsid as an independent legitimacy. It can create its own laws and become a means to perform tarjih. In the meantime, the second group claims that maquasid is not seen as an independent legitimacy. To that end, maqūsid is powerless before the texts of the Islamic law and $i j m \vec{a}$. At last, the third group is the moderates who always keep the maquasid in balance with the existing texts of Islamic law. The last opinion seems closer to the truth as it is in line with the rules of law and common sense and goes along with the benefits for all human beings.

The last opinion mentions the maqūsid al-sharīat by its nature is based on the Islamic law. This means it follows legal arguments and guidance. To that end, it cannot be separated from legal rules and theorems. As commonly known, the balance used in determining whether something brings maslahat (benefits/public interest) or mafsadat (harms) is the law. Here, the maquasid al-sharíat is the essence of the texts, laws, qainnat (legal clues) and illät (legal causes). A strong bond between the maqāsid and legal arguments resembles the relationship between kulliyyāt and juz'ìyāt.

Meanwhile, the opinion which sees the maqūsid as an independent legitimacy points out the function of 'aql (reason/intellect) in finding the benefits in every issue. The rapid development and emergence of problems which come after one another causes the limited number of texts to be unable to provide legal solutions. To this end, implementing the maquasid al-sharíat in order to open a gap in order to move and make legal decisions according to the demands of the changing times is necessary. 
Maqūisid al-sharīat or mașlahat sharizyah can be considered as a legal source if it meets the criteria to protect and preserve the seven fundamental elements: hifz al-din, hifž al-nafs, hifz al-aql, hifž al-nasl, hifz al-mäl, hifz al-ird and hifz al-bíat (protection and preservation of religion, soul, intellect, lineage, property, dignity, and environment respectively), which are commonly known as kulliyyät sabiah. These five (original) or seven (with the last two additions) fundamental elements are classified into three consecutive phases, i.e. darüriyyāt (primaries), häjiyyāt (secondaries), and tabsiniyyāt (tertiaries). The restriction of maquasid which is limited to the five elements is based on istiqra $\vec{a}$ (inductive reasoning). However, some Muslim scholars include hifz. al-ird (protection and preservation of dignity).

Muslim scholars have illustrated the maquạsid and its application in performing istinbāt. Imam Shațibi, for example, suggests the requirement to be eligible to perform Ijtihäd is when a person is capable of understanding the maqāsid perfectly. Only by then, he/ she is able to perform an istinbāt (law-making) from the maqāsid point of view.

A contemporary legal decision can be made by applying the maquasid which is supported by arguments. One of the examples is the issue about istinsākh (cloning). Muslim scholars claim that cloning is illegal due to the fact that it is not in line with the notion of hifz al-nasl (protection and preservation of lineage) and other maqūsid. The tendency to apply maqāsid, in this case, does not necessarily mean to exclude the arguments mentioned in the texts in making legal decisions. In fact, the decision made is said to be automatically in accordance with the arguments claiming about the maqāsid.

Another example is related to zakät mustaghallät which is zakāt on properties that can bring profit to the owners by leasing or selling the properties such as villas, factories, hotels, cars, aircraft, ships and other means of transportation. According to some scholars, such properties are not subject to $z a k \bar{a} t$ as they are not included in the types of wealth in zakāt. On the other hand, some others argue that the properties are bound to $z a k \bar{a} t$ considering that they are included in the types of wealth subject to zakāt and that the illāt of paying the zakāt has been fulfilled; the wealth has grown steadily. The obligation of paying zakät for the properties is according with the wisdom of paying it, which 
is to purify the wealth and to help people in need. If the owners of plants and fruits who only get low profits are required to pay zakāt, it would not make sense if the owners of villas or factories who get high profits do not pay it.

The issue on human organ transplantation also demands the presence of Ijtihäd to create its legal solution. Several questions have arisen: Is human or animal organ transplantation legal to save a human's life? Is the transplantation permitted if the animal donor is a dog? Can someone give up his/her whole or parts of body after his/her death for anatomic study so that it can be useful for others? and many other questions which require maqūsid in the contemporary Ijtihäd.

Promoting contemporary Ijtihād, both Ijtihād intiqāi and Ijtihād insh $\vec{a} \dot{i}$, play an important role in solving and answering any problems faced by Muslims nowadays, particularly if no legal provision is available. Ijtihäd intiqai, for example, is an Ijtihäd method to choose one of the opinions expressed by former scholars by performing tarjiz to show that one opinion is better than the other. This method is expected to harmonize the opinions of scholars and to refer to the arguments they have used. In the end, the strongest argument which meets the standards of tarji

In the meantime, Ijtihäd inshäi means performing istinbāt on a legal issue which has not been mentioned by former scholars. The obligation to pay zakāt on factories, villas for rent, or hotels, for example, is mentioned by Sheikh Abu Zahrah, Sheikh Abd alWahhāb Khallāf, and Sheikh Abdur Rahman Hasan. Their opinion is eventually justified by al-Qaradawi in his book, Fiqhu al-Zakāt, as it has a stronger argument (räjih).

The next type of Ijtihäd is a combination of ijtihäd intiqa'i and ijtihäd inshäi. This means choosing the opinion of former scholars and adding it with new element of Ijtihäd. The example is an Ijtihäd conducted by the Religious Advisory Body, Kuwait, concerning abortion. Their fatwa refers to the opinion of former scholars and is supported with the result of a new Ijtihäd according to the science and technology advances in modern medicine. With modern devices, the state of the embryos can be detected earlier if they are exposed to any disability or illness that can affect their body or mind after they are born. 
The fatwa says that a doctor is not allowed to abort or terminate pregnancy that has reached one hundred twenty days, except to save the mother's life from a real danger. In such case, the abortion or termination is permissible under the agreement of the husband and his wife and the pregnancy has not reached forty days. However, if the pregnancy is more than forty days, but less than one hundred twenty days, the abortion is not permissible unless the existence of the embryo would endanger the mother's health due to the embryo's disease that may lead to her death or chronic pain after giving birth. In addition, an abortion is allowed if the embryo to be born is believed to be exposed to severe disability or acute disease impairing its body or mind and unrecoverable or curable. The abortion outside of the darürāt (emergency) circumstance is required to be performed in government hospitals. In the meantime, the abortion taken after forty days of pregnancy should not be done except by the decision of three specialists, one of whom has specialty in chronic diseases in pregnant women and birth, and one of the other two specialists is a Muslim.

\section{Conclusion}

Referring to the discussion, the following conclusions are made:

Maqūsid al-sharīat is also known with maqāsid al-Shāri, maqūșid al-sharíat, and al-maqāsid al-shar'iyyat. Essentially, these different terms imply the same meaning, the purposes or objectives of the Islamic law enactment. Generally, the Muslim scholars of Islamic Jurisprudence interpret maqāsid al-shari'at as the essence of the Islamic law enactment. The general principle of maquasid al-sharíat is enforcing the significance of jalb al-masăliḥ wa dar' al-mafäsid (getting benefits and avoiding harms).

Maqāsid al-sharíat is an independent legitimacy as it points out the function of a $a l$ (reason/intellect) in finding the benefits in every issue. The rapid development and emergence of problems which come after one another causes the limited number of texts to be unable to provide legal solutions. To this end, implementing the maqussid al-sharíat in order to open a gap in order to move and make legal decisions according to the demands of the changing times is necessary. 
There are two major and significant roles of maqūsid al-sharī'at worth studying, directive and defensive systems. The directive system puts the maquasid al-sharíat as the main reference for any reformation or changing processes of the Islamic law, whereas the latter places it as the supreme principle of morality that provides the foundation and ethical-spiritual power for Muslim Societies when they interact with the law. With these two roles, the maquasid al-sharíat is no longer said to be an obstacle for any reformation as addressed by the philosophy of materialism which states that religion (i.e. Islamic law) is opium to society. In contrast, a religion can serve as a driving force to create future changes towards a more constructive and humanistic society.

\section{Acknowledgment}

This study is self-funded. Nevertheless, the authors would like to express their gratitude to all librarians at State Islamic Institute of Tulungagung for their tireless and time-consuming assistance in providing valuable materials (books, journals, etc.) during the study.

\section{References}

Ali, Abdullah Yusuf. (1992). The Meaning of the Holy Qur'ann. Maryland, USA: Amana Corporation. ISBN-10: 0915957329, ISBN-13: 978-0915957323 Amier, Nuruddin. (1987). Ijtihad Umar bin Khattab. Jakarta: Rajawali Pers. Arief, Abdul Salam. (2017). 'Ijtihad dan Dinamika Hukum Islam', IN RIGHT: Jurnal Agama dan Hak Asasi Manusia, 7(1): 1-15. Yogyakarta: UIN Sunan Kalijaga. http://ejournal.uin-suka.ac.id/syariah/inright/article/view/1455. Accessed on Jan 19, 2019.

al-Asqallānī, Syihāb al-dīn Ahmad ibn 'Alī ibn Hajar. (1995). Tahdhīb al-Tahdhīb, Beirut: Dar al-Fikr.

Auda, Jasser. (2008a). Maqashid Shariah as Philosophy of Islamic Law: A Systems Approach. London: IIIT. ISBN: 978-1-56564-425-0.

. (2008b). Maqūșid al-Sharīat: Dalïl li al-Mubtadì̃n, London: al-Ma'had al-Alami li al-Fikr al-Islami (IIIT).

(2015). Membumikan Hukum Islam melalui Maqasid Syariah, $1^{\text {st }}$ ed., Translated by Rosidin and 'Ali 'Abd el-Mun'im, Bandung: Mizan Media Utama.

al-Awwa, Muhammad Salim. (1998). al-Fiqh al-Islämîî̀ Tarīq al-Tajdîd, Beirut: al-Maktab al-Islāmī. 
Bailey, K. D. (2007). Methods of Social Research. $4^{\text {th }}$ ed. New York: The Free Press. ISBN-10: 1416576940, ISBN-13: 978-1416576945.

Bakrie, Asafri Jaya. (1996). Konsep Maqashid Syariah menurut al- Syatibi, $1^{\text {st }}$ ed., Jakarta: P.T. Raja Grafindo Persada, ISBN: 979421549X, 9789794215494

de Bellefonds, Y. Linant. (1956). 'La Suppression des Juridictions du Statut Personnel en Egypte' [The Suppression of Personal Status Jurisdictions in Egypt], Revue International du Droit Compare, 8(1): 412-425. https:/www. persee.fr/doc/ridc_0035-

337_1956_num_8_3_10932. Accessed Feb 25, 2019.

Bsoul, Labeeb Ahmed. (2016). Formation of the Islamic Jurisprudence: From the Time of the Prophet Muhammad to the 4 th Century, $1^{\text {st }}$ ed. London: Palgrave Macmillan. ISBN-e: 978-1-137-57869-3, ISBN-p: 978-1-137-58089-4. doi: 10.1057/978-1-137-57869-3.

al-Bukhari, Muhammad. (1986). al-Ṣahīh, edited by Musthofa al-Bugha, $3^{\text {rd }}$ ed. Beirut: Dar Ibn Katsir.

Bustamam-Ahmad, Kamaruzzaman. (2007). The Application of Islamic Law in Indonesia: The Case Study of Aceh, Journal of Indonesian Islam, 1(1): 135-179. DOI: 10.15642/JIIS.2007.1.1.135-180

al-Būṭī, Sa'īd Ramad\}ān. (1990). Dawābit al-Maṣlaḥat fi al-Sharīat al-Islāmiyyah. Beirut: Muassasah al-Risālah.

Carvalho, Christina. (2010). 'Christiaan Snouck Hurgronje: biography and perception', $M A$ thesis, Amsterdaam: Universiteit van Amsterdaam. https:// arno.uva.nl/cgi/arno/show.cgi?fid=168795. Accessed on Feb 1, 2019.

Coulson, N. J. (2011). A History of Islamic Law, New Jersey-USA: Aldine Transaction.

Creswell, John W. (2014). Research Design, $4^{\text {th }}$ ed. Thousand Oaks, CA: SAGE. al-Fasi, 'Allal. (1993). Maqūsid al-Sharī'at al-Islämiyyah wa Makārimuhā. RabathMorocco: Maktabah al-Wahdah al-Arabiyyah.

Ghazali, Abdul Moqsith. (2005). 'Merancang Kaidah Ușūl Fiqih Alternatif.' In Negara dan Civil Society: Gerakan dan Pemikiran Islam Kontemporer, K. Hidayat \& A. Gaus (eds.), Jakarta: Paramadina, pp. 352-370. ISBN: 9798321995.

al-Ghazālī, Abu Hamid. (2018). 'Al-Mustaṣfā min 'Ilm al-Uṣūl'. In Al-Mustasfā min Ilm al-Ușül: On Legal Theory of Moslem Jurisprudence, AZM Hammad (trans.), Carolina: Create Space Independent Publishing Platform. ISBN-10: 1984129899, ISBN-13: 978-1984129895.

Hakiki, K. M. (2016). 'Islam dan Demokrasi: Pandangan Intelektual Muslim dan Penerapannya di Indonesia', Wawasan: Jurnal Ilmiah Agama dan Sosial Budaya, 1(1): 1-17. DOI: 10.15575/jw.v39i1.583.

Hallaq, Wael B. (2005). The Origins and Evolution of Islamic Law [Themes in Islamic Law], $1^{\text {st }}$ ed. Cambridge: Cambridge University Press. ISBN-13: 978-0521005807, ISBN-10: 0521005809. 
Hasan, Nur. (2019). 'Maqashid Syari'ah di Masa Awal Islam', Alif.id, May 3, https://alif.id/read/nur-hasan/maqashid

-syariah-di-masa-awal-islam-b217904p Accessed May 5, 2019.

Hasanah, Uswatun. June 2013). 'Asuransi Dalam Perspektif Hukum Islam', AsySyir'ah:Jurnal Ilmu Sharīat dan Hukum, 47(1)): 239-268. Available on: www.asy-syirah.uin-suka.com/index.

php/AS/article/download/63/63. Accessed on Jan 14, 2019.

Hazri, Tengku Ahmad. (2015). 'Balancing Text and Context through Maqasidbased Ijtihad', Islam and Civilisational Renewal, 6(3): 422-426. https:// icrjournal.org/index.php/icr/article/view/507/468

Ibn 'Ashūr, Muhammad al-Tahir. (2006). Maqāsid al-Sharī'at al-Islāmiyyah. In Treaties on Maqāsid al-Sharīat, MT el-Mesawi (ed.), London: The International Institute of Islamic Thought (IIIT).

Ibn Hanbal, Imam Ahmad Imam Ahmad. (1978). Musnad Imām Abmad bin Hanbāl. Cairo, Muassasah Qurtubah.

Ibn Hazm, Abu Muhammad 'Ali. [n.d.]. Al-Muhallā, Vol.3, $1^{\text {st }}$ ed., edited by Lajnah Ihya al-Turats al-Arabi, Beirut: Dar al-Afaq.

Ibn Khaldun, Abd al-Rahman. (2001). 'Muqaddimah', In Muqaddimah, Masturi Irham (trans.), Jakarta: Pustaka al-Kautsar.

Ibn al-Subkī, Tāj al-Dīn 'Abd al-Wahhab, [n.d.]. Hashīah al-Allamah al-Bannāni 'alā Matn Jamii al-Jawāmi, chapter II, Cairo: Dar Ihya' al-Kutub al 'Arabiyyah.

Isma'il, Sha'ban Muhammad. (1985). Al-Tashrī’ al-Islāmi: Mașdaruh wa Atwāruh, Cairo: Maktabah al-Nahḍah al-Miṣriyyah.

Isra, Yunal. (2018). 'Maqashid Syari'ah dalam Ijtihad Para sahabat Nabi', Bicang Syariah, July 30, Available on: https://bincangsyariah.com/kalam/

maqashid-syariah-dalam-ijtihad-para-sahabat-nabi/ accessed on Feb 28, 2019.

Junaidi Lbs. (2014). 'Elastisitas Hukum Islam dalam Merespons Perubahan Sosial', Madania, 18(1): 67-78. https://ejournal.iainbengkulu.ac.id/index. $\mathrm{php/madania/article/view/4/4}$

al-Juwayni, Abd al-Malik ibn Yusuf Abu al-Ma'ali. (1400 H/1980). Al-Burhān fì Ușūl al-Fiqh, Cairo: Dār al-Anșār.

Khallaf, Abdul Wahab. (1982). Masādir al-Tashrì̀ al-Islāmi fì Mā Lā Nașsa Fīhi. Kuwait: Dār al-Qalam.

Khasan, Moh. (2008). 'Kedudukan Maqashid al-Syari'ah dalam Pembaharuan Hukum Islam', Dimas 8(2): 296-314. Available on: http://eprints.walisongo .ac.id/7231/1/Khasan_Maqasid_dan_Pembaharuan_Hukum.pdf. Accessed on Feb 24, 2019.

Khatib, Suansar. (2014). 'Eksistensi Nasakh dalam Implementasi Elastisitas Hukum Islam', Madania, 18(1): 79-86. https:/ejournal.iainbengkulu.ac.id/ index.php/madania/article/view/3 
Madkur, Muhammad Salam. (1983). Al-Ijtihād fì al-Tashrī’ al-Islāmī, Cairo: Dār al-Nahḍah al-'Arabiyyah.

Mahmashani, Subhi. (2000). 'Falsafah al-Tashri' fi al-Islām'. In The Philosophy of Jurisprudence in Islam, Farhat Ziadeh (Trans. and ed.). Kuala Lumpur: The Open Press. ISBN: 9679901076.

Masood, Muhammad Khalid. (1998). Shatibi's Philosophy of Islamic Law, New Delhi: Kitab Bhavan. ISBN-10: 8171512348, ISBN-13: 978-8171512348.

Mubarok, Jaih. (2003). 'Dinamika Pemikiran Hukum Islam di Indonesia', Jurnal Unisia, 48/XXVI/II: 103-121. https://journal.uii.ac.id/Unisia/article/ download/5290/4708

Musa, Kamil. (1989). al-Madkhal Ilā al-Tashrì al-Islàmī, Beirut: Muassasah alRisālah.

Nawawi, Hadari. (1991). Metode Penelitian Bidang Sosial, Yogyakarta: Gajah Mada University Press.

Nur, Iffatin. (2008). 'Maqashid al-Syari'ah: Telaah Asal Usul dan Perkembangan Konsep Maqashid al-Syari'ah al-Syathibi', Doctorate diss. Jakarta: UIN Syarif Hidayatullah, (unpublished).

Payne, G. and Payne, J. (2004). Key Concepts in Social Research. London: SAGE. ISBN: 076196542 4, ISBN: 0761968432

al-Qaraḍawi, Yusuf. (1985). Al-Ijtihād fì al-Sharīat al-Islämiyyah màa Naẓāti Tahlìliyyāt fì al-Ijtihād al-Mu'āsir, Kuwait: Dar al-Qalam. (1994). Ijtihād al-Mu'āsir Bayna al-Indibāt wa al-Infirāt, Cairo: Dār al-Tauzi wa al-Nashr al-Islāmiyah.

al-Qarafī, Syihab al-Din Ahmad ibn Idris. (1973). Sharh Tanqih al-Fusūl, Cairo: Maktabah al-Kulliyah al-Azhar and Dar al-Fikr. (1994). al-Dhākirah, vol. 5. Beirut: Dar al-Arab, 1994.

al-Raisūnī, Ahmad. (1992). Nazariyyah al-Maqāsid 'inda al-Imām al-Shatibi, Riyadh: Dār al-Ilmiyah li al-Kitab al-Islāmi.

Rauf, Muhammad Abdul. (1989). 'Al-Hadith: Its Authority and Authencity', IIU Law Journal, 1(1): 1-50.

Saputra, A. (2019). 'Indonesia Ranking 89 Indeks Persepsi Korupsi Dunia', detikNews, Jan 29. Retrieved from: www.news.detik.com/fotonews/d-4405951/indonesia-ranking-89-indeks-persepsi-korupsi-dunia. Accessed March 19, 2019.

Schacht, Joseph. An Introduction to Islamic Law, Oxford: Oxford University Press, 1996.

Setiawan, Boenjamin. (2014). 'Aplikasi Terapeutik Sel Stem Embrionik pada Berbagai Penyakit Degeneratif', Cermin Dunia Kedokteran, 153. Available online on: https://studylibid.com/doc/511580/

aplikasi-terapeutik-stem-sel-embrionik-pada-berbagai-peny..., accessed on 10 March 2019. 
al-Shațībī, Abu Ishaq and Daraz, Abdullah [ed.]. (1999). Al-Muwãaaqāt fì Usūl al-Sharīat. $4^{\text {th }}$ ed. Beirut: Dār al-Mảrifah.

Suhaylī, Muhammad Amin. (2010). Qã̃idat Dar' al-Mafäsid awlā Min Jalb alMașälih: Dirāsah Tablizlizyah, Cairo: Dar al-Salam.

Sya’bani, Akmaludin. (2015). 'Maqashid al-Syari'ah sebagai Metode Ijtihad', ElHikam, 8(1): 127-142. http://ejournal.kopertais4.or.id/sasambo/index.php/ elhikam/article/view/1386

al-Ṭabarī, Abu Ja’far. (2000). Jāmi’ al-Bayān fì Tảwīl al-Qurānn. Beirut: Dar al-Kutub.

Thahir, A. Halil. (2019). Ijtihad Maqashidi: The Interconnected Mașlahat-Based Reconstruction of Islamic Laws Geneva: Globethics.net. ISBN-o: 978-2 -88931-220-7, ISBN-p: 978-2 -88931-221-4

al-Ṭurabi, Hasan. (1975). Tajdìd al-Fikr al-Islämi, Cairo: Dār al-Kutub.

Wahyuni, Afidah. (2016). 'Teori Tafsir dalam Perspektif Kebahasaan: Terminologi Tafsir, Ta’wil Dan Ta’lil', Mizan: Jurnal Ilmu Syariah, 4(2): 225-252. https:// www.jurnalfai-uikabogor.org/

index.php/mizan/article/view/172/87

Zed, Mestika. (2008). Metode Penelitian Kepustakaan, Jakarta: Yayasan Obor Indonesia. ISBN: 978-9-79461-888-2.

Iffatin Nur ${ }^{1}$, Syahrul Adam, and M. Ngizzul Muttaqien ${ }^{3}$

${ }^{1,3}$ Institut Agama Islam Tulungagung, Jawa Timur, Indonesia

${ }^{2}$ Universitas Islam Negeri Syarif Hidayatullah Jakarta, Indonesia

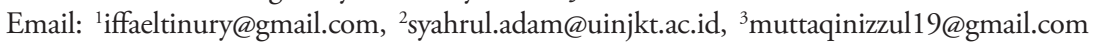

